\title{
The Geography of Black Candidate Electoral Success
}

\author{
Marcus Allen and Marvin King
}

In this manuscript, we reexamine claims about the geography of electoral success of African American candidates. Barack Obama's historic election in 2008 prompted journalists, partisans, and scholars to review prior notions of where African American candidates can successfully contend for elected office. Although Obama's victory is just an anecdotal national example (albeit an important one), we review the available evidence at the state level to understand what factors might impede African American electoral success. Heretofore, the literature focused on the density of the black population, and the interconnectedness of region and white racial attitudes. This paper shows that these old standbys can no longer explain African American electoral success.

Following the presidential election of 2008, Americans and non-Americans alike expressed amazement that the United States elected an African American as president. Beyond the historical significance of the racial ramifications of the election, Obama surprised seasoned political observers with where he won Electoral College votes, impressing people that he won in states like Florida, North Carolina, and Indiana. Obama's electoral success then prompted a logical question we seek to answer. Are there now no limits on where African American candidates can do well in terms of winning legislative office, or was his win unique? More broadly, beyond the obvious locales in which Democratic candidates generally enjoy electoral success, in which particular geographies do African American candidates demonstrate more electoral success? What factors might account for this success?

Our interest is in examining, time and given the African American population, the success in electing black candidates to state legislatures. Early research often focused at the local level (Bullock 1975). Comparatively little research focuses on African American electoral success at the state level, and that most often focuses on how minority legislators differ from white legislators once elected (Barett 1994; Preuhs 2006). The bulk of previous research (Lublin 1997; Voss and Lublin 2001) exhaustively investigated the likelihood, geography and political effects of electing African Americans to the U.S. House of Representatives, specifically in majorityminority districts.

With a state level focus, we investigate whether blacks have more political strength (as measured in their ability to elect black candidates on

MARCUS ALLEN is an assistant professor of political science at Wheaton College.

MARVIN KING is assistant professor of political science at the University of Mississippi.

The American Review of Politics, Vol. 30, Winter, 2010-2011: 333-356

(C)2010 The American Review of Politics 
par with their population in the state). In other words, are blacks politically stronger in some states over other states? Importantly, the question involves not merely determining where the number of black elected officials is at parity with the state's black population. Political contexts are not uniform across states, and we should weigh our standards of electoral success accordingly. We need metrics to determine whether the number of black elected officials is over or under expectations, and we must put this relative success against the backdrop of the ideological leanings of each state, whether the state is in the South, and the total black population. We believe measuring electoral success is about more than just geography. We explore this question through an application of descriptive statistics, bivariate analysis and logistic regression. Pursuant to that goal, our research focuses on understanding where, given at two distinct points in time and given the voting profile of each state, have African American candidates been most successful at winning state legislative office. We can then use this information to begin to understand why African Americans achieve racial overrepresentation in some states and underrepresentation in other states

Previous research has tackled the question of the role electoral geography plays in the electoral success of African American candidates. For instance, attempts to explain African American electoral success often point to the density of African American population in urban areas such as Atlanta, Chicago, or Detroit. A complementary explanation, assessing blame for the failures of African Americans candidates, relies on white attitudes (racism) and the regional peculiarities of the South as twin scapegoats. We believe though, the election of Barack Obama demands that we update our understanding of where and why African American candidates are most likely to find electoral success.

\section{Updating the Literature}

Scholars have always considered race a paramount issue for both black voters and black candidates. Literature shows that black voters rely heavily on racial consciousness, which is the belief that people derive their concept of self from membership in a social group and that people attach an emotional significance to that very membership (Davis and Brown 2002). Tajifel (1978) writes that, in general, people's categorizations of in-group members lead them to certain cognitive evaluations of both in-group and out-group members. Often, especially for minorities, there is a particularly strong event serving as a primary rallying point to a shared characteristic and this becomes a "frame of reference for members' political attitudes and behavior." The Civil Rights movement served this purpose for the black community, helping to make political action and political beliefs synonymous with skin 
color. Probing the essence of group consciousness, the 1996 National Black Election Studies asked several questions requiring black respondents to think of how important "consciousness" is to their lives. The results unequivocally demonstrated that clear majority African Americans believe that most black Americans share a "linked fate."

Conover (1984) considers group identification and sees the influence that group membership has on a person as a function of social interaction among group members, group cohesiveness, and perceptions of shared selfinterest. It follows that "people structure their perceptions of social events and objects in terms of categories (such as racial/ethnic groups), and that the process of categorization in and of itself can influence how people think and behave." For instance, among Hispanics there was a visceral reaction to two GOP-sponsored initiatives, to deny welfare services to legal immigrants and to undermine affirmative action. This partly explains Clinton's steep gains in attracting more Latino voters in California in 1996 over 1992. Group consciousness theory advocates that minority voters support the party that they identify as most strongly benefiting their ethnic group (Shingles 1981). Dawson (1994a) contends, "Blacks' belief that their fate is tied to that of other blacks serves as a powerful component of racial identity."

Looking beyond race, at in-group and out-group effects, we come to a discussion of descriptive representation. Descriptive representation holds that a minority group achieves the best representation from an office-holder sharing certain physical, descriptive characteristics. There is a shared concern (Guinier 1994; Hero and Tolbert 1995; Burns et al. 2001), that governmental decisions underrepresent minorities' preferences and that descriptive representation is a laudable goal. The perceived benefit of descriptive representation is that it eventually leads to greater political equality for African Americans, Latinos and women (Newman and Griffin 2005). To achieve this, mapmakers in many states draw voting district boundaries around areas with large numbers of minority voters, to ensure that a block of minority votes is not split and dissipated between predominantly white districts. Consequently, a black candidate has an optimal chance to win a majority in one of these districts. This increased likelihood of success increases the number of black candidates, which has the additional benefit of increasing black turnout (Gay 2001). African Americans' evaluations and orientations towards government do change with increased African American representation (Bobo and Gilliam 1990; Fenno 2003; Tate 2003).

\section{Electoral Geography}

We see that race is a powerful influence on the African American voter. Previous dogma held that the consequences of race were equally powerful 
for the black candidate. It was assumed that a black candidate could only win elective office in a district with a large black population. That is, regardless of the elective office, without a large black population, a successful black candidacy was impossible. Obama's win in the 2008 Iowa caucuses forces us to throw out this old assumption, and look anew at other influencing factors, which we will do in the following sections.

Racially polarized voting could easily preclude the election of minority candidates; however, as Grofman and Handley (1989) demonstrate, when voting districts are drawn to emphasize minority voices, states can provide a geographic end-around to this predicament. Small voting districts make it easier for minorities to elect minorities, and Lublin (1997) demonstrates that at certain cut points, when eligible black voters compose a certain percentage of the electorate, the chance of electing an African American candidate increases dramatically.

Grofman and Handley's (1989) authoritative examination of African American representation concludes that electoral geography (i.e., the physical location of the district) best explains variation in black representation by section and type of office. Similar conclusions about that era's elections came from Brace et al. (1987) and Engstrom and McDonald (1981). Grofman and Handley held that electoral success for blacks could be found at the intersection of black density (raw numbers and in population percentages), and the size of the constituency unit. However, Grofman and Handley's geographic-centric conclusion omits the variable of state ideology, which we believe to be a critical factor and which we discuss below. ${ }^{1}$

\section{White Attitudes, Black Candidates}

Despite Grofman and Handley's conclusions, most will agree that racial attitudes have changed since the eighties. Using 1996 and 1998 congressional exit poll data, Highton (2004) found little evidence that white voters discriminated against African American candidates.

However, contrary to Highton (2004), Sigelman et al. (1995) show that many white voters apply stereotypes to black candidates and these stereotypes can negatively affect candidates' chances of winning elective office. This is especially true of liberal black candidates. McDermott (1998) finds that voters typically stereotype office seekers, and they stereotype female and black candidates as liberal. Using survey instruments from 1987 and 1988, Williams $(1990,47)$ found that white voters, "knowing nothing more about candidates than their race reported that politicians of their own race would be more likely to achieve [their] goals than black politicians."

Particularly instructive is that white voters were more likely to attribute the label "liberal" to black Democratic candidates than white Democratic 
candidates; this was especially true of self-identified conservatives and Republican-party identifiers. This happens because voters expect black candidates to concern themselves primarily with minority rights (McDermott 1998). This is especially meaningful for down-ballot, low-information elections, such as those for the state House. Conservative voters, then, are less likely to give black candidates the opportunity to prove that they are moderate or even conservative. In addition, Williams (1990) finds that crossover voting is less likely when blacks aim for higher office, although here the evidence is mixed. For instance, take Tom Bradley's ill-fated 1982 campaign for governor of California. Citrin et al. (1990) found that race had no effect because conservative whites opposed all Democratic candidates, not just Bradley, yet Henry (1982) argues that enough white Democrats defected from Bradley to provide a patina of evidence that many whites were uncomfortable with electing a black to statewide office.

However, for blacks to routinely win in districts other than majorityminority districts - as Barack Obama did — they must foster racial crossover voting, wherein white voters support black candidates at the polls. Many refer to this as deracialization (Gillespie 2010). Apart from race, because most African American candidates run for office as Democrats, this typically limits the chances of black electoral success to areas where Democrats traditionally do well. That is, if no Democrats do well in a particular area, it is unlikely an African American Democrat will do well. However, the inverse is not true. In areas where white Democrats do well, there is no guarantee that a black Democrat can also do well. At least that is what we have always thought.

Certainly, African American success at U.S. House elections is modest. Canon (1999) found that, in House elections held in majority white districts between 1966 and 1996, African Americans won only 5.3 percent of the elections. The leading hypothesis explaining such outcomes as illustrated by Canon is simply that white voters prefer white candidates to black candidates (Jones and Clemons 1993; Reeves 1997). Bullock and Dunn (1999) estimate that, in the South, white Democratic candidates receive roughly 10 percent more of the white vote than black Democratic candidates. Gay (1999) finds that support for black candidates is 10 percent less than support for white candidates, but generalizing from this study might be problematic due to its sampling of just five states and eight black candidates. Researchers relying on experimental evidence have come to similar conclusions, finding that prejudice leads white voters to discriminate against black candidates (Moskowitz and Stroh 1994; Terkildsen 1993). This occurs because assumed characteristics of out-group members influence how voters perceive minority candidates (Sigelman et al. 1995). 
This state of affairs need not be permanent. Majority voters do modify the pre-packaged set of characteristics they attribute to minority candidates. Hajnal (2001) finds that black electoral success can beget additional black electoral success. Positive experience with black incumbents decreases racial tension, increases racial sympathy, and increases support for black leadership among white Democrats and Independents (the most common types of white voter found in urban cores). A critical point then, but one not often emphasized, is that in the South where there are a higher aggregate number of elected African Americans, a cycle of electoral success might exist.

Recently white voters have expressed increased willingness to vote for black candidates (Feree 1974; Schreiber 1978; Sigelman and Welch 1984). Still, as late as 1987 , white voters perceived white candidates to be more trustworthy, intelligent, hardworking, and knowledgeable than black candidates. Alternatively, there is evidence that race has little effecteven that on particular issues black candidates are advantage (Reeves 1997; Sigelman et al. 1995). Philpot and Walton (2007) find that most voters treat black female candidates much like any other candidate. The exception is the black female voter who is disproportionately supportive of black female candidates. "Support for black female candidates is contingent on their background and political experience. Black female candidates with significant experience in politics can attract both black and white voters, regardless of gender" $(2007,49)$.

The literature finds that crossover voting, the level of the office, black incumbents and gender are all influential in black electoral success. In addition, the political climate, opponent quality, campaign professionalism (Squire 1992) and a flexible campaign strategy (which may or may not mean a deracialized campaign) are each crucial elements of black electoral success.

\section{African American Electoral Success in State Legislatures Geography and State Ideology}

In the past, researchers have assumed that African American electoral success for state legislative offices depends on the confluence of population density, region and state ideology. It was assumed that the electoral success of African Americans for local office depends on a dense black population (regardless of state ideology). Second, the electoral success of African Americans for state legislative offices depends on a dense black population plus a preferred (liberal) state ideology. We will examine each of these factors. 


\section{Density}

One purpose of the 1965 Voting Rights Act was to eliminate voting practices with discriminatory impacts on the ability of African Americans to elect their preferred candidates. common practice was creating at-large districts or drawing ward district lines to dilute minority voting strength. A series of court cases have ruled that mapmakers cannot draw district lines in such a fashion that they solely take into account race, yet neither can they draw district lines diluting minority voting strength. ${ }^{2}$

However, Barack Obama's success demonstrated that high black density was not an essential element in a high-profile presidential race. The recent successes of a few congressional African American candidates also indicate that high black density is not essential to African Americans in state legislative races. Influential factors do include smaller populations of legislative districts, diverse local campaign issues, and the passage of time, which has made white voters more comfortable with black representation. The preceding discussion, about the density of the black population and its influence on African American electoral success, leads to the following hypothesis:

Hypothesis 1: African American candidate electoral success for state legislative elections is not dependent on black density.

\section{Region and State Ideology}

We see African American electoral success as the intersection of electoral geography and state ideology. The changing nature of Southern politics requires us to look beyond electoral geography alone. We seek to move beyond past explanations of race and a South/non-South binary relationship (although we do test for the existence of this relationship). Likewise, the damping of overt racial hostility encourages us to expand our investigation beyond geographic or race-based explanations, to establish an explanation for African American electoral success based on both electoral geography and state ideology. It is our hope this model will be more parsimonious than previous efforts because we will use variables that are easier to score than regional prejudice, which is important but not easily defined. We will instead use measures of demographic and partisan data.

Therefore, we introduce another factor that influences the electoral success of African American black candidates: state ideology, how conservative or liberal a state is, overall. In conservative states, the density of the black population limits the absolute number of winning black candidates. As states become less conservative, the number and likelihood of successful African American candidates increases, even if the absolute black density decreases. 
The same is not true for white candidates, regardless of partisan affiliation; state ideology has no impact on white candidates' success. Research has shown the impact of state ideology on a range of outcomes. For example, state ideology affects the growth in black imprisonment rates and black imprisonment disparity (Yates and Fording 2005). In his examination of black candidates' success, Sonenshein (1990) observed that liberal racial attitudes are requisite in winning statewide elections.

Conventional wisdom might suggest it is best to combine the hypothesis testing for region and state ideology. The South is more conservative ideologically than the non-South. True, but that would confuse the real purpose of this research, which is to understand if, despite the South's conservatism, African Americans are largely successful at electing black candidates. An example should prove illuminating. Mississippi, Alabama and South Carolina are each among America's more conservative states, yet each of these states lead in the total number of black elected public officials (Bositis 1998). This, of course, still does not answer whether the number of blacks elected in these states is proportional to their actual numbers. The preceding discussion leads to the following hypotheses:

Hypothesis 2: The more conservative the state, the less likely African American candidates are to enjoy electoral success in state legislative races.

Hypothesis 3: At the state level, there is no difference between the South and non-South when measuring the likelihood of African American candidates winning electoral office.

\section{Design, Data and Method}

At the outset of this project, we stated our interest in the probability of winning electoral office for African Americans at the state and congressional level. Although we are interested in variations over time, because there is little variation in the election cycle within each decennial period, a time series model would not be appropriate. The American electoral cycle for legislatures is every two years for most states. We elected to use two crosssections at optimal points in two decades, 1996 and 2007. We selected these time points for two reasons. First, it is in consideration of the manner in which the National Council of State Legislatures reports the data. The organization's website, www.ncsl.org, contains a wealth of data on state legislative election information, including the number of African American state legislators. Second, within any given Census period, there is very little variation in the proportion of black state legislators to the black population - too little 
variation to warrant including more years in this analysis. By 1996, state legislative districts fully reflected the changes to political boundaries and the sizeable increase in African Americans' descriptive representation in state legislatures as a result of the 1990 Census. The same holds for 2007, and so the legislative composition for these two years will serve to test our hypotheses.

We borrow the measure of state ideology developed by Robert Erikson and Gerald Wright (1993). Their measure aggregates numerous state public opinion polls to derive a measure of state ideology on the continuum of conservative to liberal. The primary statistical method is logistic regression and we do not use the odds ratio or logged likelihood for interpretation purposes because of accessibility. In order to provide more substantive meaning, we illustrate the probability of success with each state for the two periods by calculating the probability of the dependent variable for each state (Tables 1 and 2).

Table 1. Predicted Probabilities of House and Senate Electoral Success, 1996

\begin{tabular}{lcccc}
\hline Region & $\begin{array}{c}\text { Black } \\
\text { Density } \\
\text { Factor }\end{array}$ & $\begin{array}{c}\text { State } \\
\text { Ideology }\end{array}$ & $\begin{array}{c}\text { House } \\
\text { Predicted } \\
\text { Probability }\end{array}$ & $\begin{array}{c}\text { Senate } \\
\text { Predicted } \\
\text { Probability }\end{array}$ \\
\hline Southern & & & & \\
Alabama & 0.35 & -23.1 & 0.06 & 0.14 \\
Arkansas & 0.19 & -18.3 & 0.29 & 0.29 \\
Florida & 0.18 & -17.1 & 0.34 & 0.31 \\
Georgia & 0.40 & -17.7 & 0.11 & 0.19 \\
Louisiana & 0.48 & -23.0 & 0.03 & 0.10 \\
Mississippi & 0.57 & -25.4 & 0.01 & 0.07 \\
North Carolina & 0.29 & -20.7 & 0.13 & 0.20 \\
South Carolina & 0.43 & -21.4 & 0.05 & 0.13 \\
Tennessee & 0.19 & -16.6 & 0.35 & 0.32 \\
Texas & 0.15 & -23.2 & 0.19 & 0.22 \\
Virginia & 0.24 & -17.9 & 0.24 & 0.27 \\
Non-Southern & & & & \\
Alaska & 0.06 & N/A & 0.98 & 0.71 \\
Arizona & 0.04 & -18.2 & 0.77 & 0.34 \\
California & 0.10 & -6.20 & 0.94 & 0.56 \\
Colorado & 0.05 & -8.60 & 0.93 & 0.54 \\
Connecticut & 0.10 & -4.40 & 0.95 & 0.60 \\
Delaware & 0.23 & -12.2 & 0.74 & 0.34 \\
& & & & $\ldots$ table continues
\end{tabular}


Table 1. Predicted Probabilities of House and Senate Electoral Success, 1996 (continued)

\begin{tabular}{|c|c|c|c|c|}
\hline Region & $\begin{array}{c}\text { Black } \\
\text { Density } \\
\text { Factor }\end{array}$ & $\begin{array}{c}\text { State } \\
\text { Ideology }\end{array}$ & $\begin{array}{c}\text { House } \\
\text { Predicted } \\
\text { Probability }\end{array}$ & $\begin{array}{c}\text { Senate } \\
\text { Predicted } \\
\text { Probability }\end{array}$ \\
\hline Hawaii & 0.07 & N/A & 0.98 & 0.70 \\
\hline Idaho & 0.01 & -27.9 & 0.47 & 0.19 \\
\hline Illinois & 0.19 & -10.1 & 0.83 & 0.41 \\
\hline Indiana & 0.09 & -16.7 & 0.76 & 0.34 \\
\hline Iowa & 0.02 & -13.5 & 0.89 & 0.45 \\
\hline Kansas & 0.07 & -15.9 & 0.80 & 0.37 \\
\hline Kentucky & 0.07 & -13.2 & 0.86 & 0.43 \\
\hline Maine & 0.00 & -14.7 & 0.88 & 0.44 \\
\hline Maryland & 0.39 & -5.70 & 0.75 & 0.37 \\
\hline Massachusetts & 0.07 & -0.80 & 0.97 & 0.69 \\
\hline Michigan & 0.17 & -8.80 & 0.87 & 0.45 \\
\hline Minnesota & 0.03 & -12.8 & 0.89 & 0.46 \\
\hline Missouri & 0.13 & -15.5 & 0.75 & 0.34 \\
\hline Montana & 0.00 & -11.1 & 0.93 & 0.52 \\
\hline Nebraska & 0.04 & -18.7 & 0.76 & 0.33 \\
\hline Nevada & 0.08 & -0.20 & 0.97 & 0.69 \\
\hline New Hampshire & 0.01 & -12.8 & 0.90 & 0.48 \\
\hline New Jersey & 0.18 & -3.40 & 0.93 & 0.56 \\
\hline New Mexico & 0.03 & -16.0 & 0.83 & 0.39 \\
\hline New York & 0.21 & -3.10 & 0.92 & 0.55 \\
\hline North Dakota & 0.00 & -26.6 & 0.53 & 0.21 \\
\hline Ohio & 0.12 & -10.1 & 0.88 & 0.46 \\
\hline Oklahoma & 0.90 & -27.3 & 0.00 & 0.02 \\
\hline Oregon & 0.01 & -7.90 & 0.95 & 0.58 \\
\hline Pennsylvania & 0.10 & -10.6 & 0.88 & 0.46 \\
\hline Rhode Island & 0.04 & -2.10 & 0.90 & 0.68 \\
\hline South Dakota & 0.00 & -24.1 & 0.62 & 0.25 \\
\hline Utah & 0.00 & -28.0 & 0.47 & 0.19 \\
\hline Vermont & 0.00 & -11.4 & 0.92 & 0.51 \\
\hline Washington & 0.03 & -5.90 & 0.96 & 0.61 \\
\hline West Virginia & 0.03 & -9.20 & 0.93 & 0.54 \\
\hline Wisconsin & 0.05 & -10.5 & 0.91 & 0.50 \\
\hline Wyoming & 0.00 & -17.8 & 0.81 & 0.37 \\
\hline
\end{tabular}


Table 2. Predicted Probabilities of House and Senate Electoral Success, 2007

\begin{tabular}{|c|c|c|c|c|}
\hline Region & $\begin{array}{c}\text { Black } \\
\text { Density } \\
\text { Factor }\end{array}$ & $\begin{array}{c}\text { State } \\
\text { Ideology }\end{array}$ & $\begin{array}{c}\text { House } \\
\text { Predicted } \\
\text { Probability }\end{array}$ & $\begin{array}{c}\text { Senate } \\
\text { Predicted } \\
\text { Probability }\end{array}$ \\
\hline \multicolumn{5}{|l|}{ Southern } \\
\hline Alabama & 0.35 & -23.1 & 0.15 & 0.09 \\
\hline Arkansas & 0.18 & -18.3 & 0.35 & 0.21 \\
\hline Florida & 0.19 & -17.1 & 0.37 & 0.23 \\
\hline Georgia & 0.44 & -17.7 & 0.19 & 0.15 \\
\hline Louisiana & 0.48 & -23.0 & 0.09 & 0.06 \\
\hline Mississippi & 0.57 & -25.4 & 0.06 & 0.04 \\
\hline North Carolina & 0.30 & -20.7 & 0.22 & 0.13 \\
\hline South Carolina & 0.43 & -21.4 & 0.14 & 0.09 \\
\hline Tennessee & 0.20 & -16.6 & 0.37 & 0.24 \\
\hline Texas & 0.16 & -23.2 & 0.25 & 0.12 \\
\hline Virginia & 0.28 & -17.9 & 0.28 & 0.18 \\
\hline \multicolumn{5}{|l|}{ Non-Southern } \\
\hline Alaska & 0.06 & $\mathrm{~N} / \mathrm{A}$ & 0.86 & 0.85 \\
\hline Arizona & 0.04 & -18.2 & 0.52 & 0.31 \\
\hline California & 0.09 & -6.20 & 0.76 & 0.69 \\
\hline Colorado & 0.06 & -8.60 & 0.73 & 0.63 \\
\hline Connecticut & 0.12 & -4.40 & 0.77 & 0.73 \\
\hline Delaware & 0.25 & -12.2 & 0.50 & 0.42 \\
\hline Hawaii & 0.07 & N/A & 0.86 & 0.85 \\
\hline Idaho & 0.01 & -27.9 & 0.31 & 0.11 \\
\hline Illinois & 0.19 & -10.1 & 0.60 & 0.52 \\
\hline Indiana & 0.09 & -16.7 & 0.52 & 0.34 \\
\hline Iowa & 0.02 & -13.5 & 0.65 & 0.48 \\
\hline Kansas & 0.08 & -15.9 & 0.55 & 0.37 \\
\hline Kentucky & 0.08 & -13.2 & 0.61 & 0.46 \\
\hline Maine & 0.00 & -14.7 & 0.64 & 0.44 \\
\hline Maryland & 0.45 & -5.70 & 0.50 & 0.55 \\
\hline Massachusetts & 0.08 & -0.80 & 0.85 & 0.83 \\
\hline Michigan & 0.19 & -8.80 & 0.63 & 0.56 \\
\hline Minnesota & 0.04 & -12.8 & 0.65 & 0.49 \\
\hline Missouri & 0.13 & -15.5 & 0.52 & 0.36 \\
\hline Montana & 0.01 & -11.1 & 0.71 & 0.57 \\
\hline Nebraska & 0.05 & -18.7 & 0.50 & 0.29 \\
\hline Nevada & 0.09 & -0.20 & 0.85 & 0.84 \\
\hline New Hampshire & 0.01 & -12.8 & 0.67 & 0.51 \\
\hline New Jersey & 0.21 & -3.40 & 0.74 & 0.73 \\
\hline New Mexico & 0.03 & -16.0 & 0.58 & 0.39 \\
\hline
\end{tabular}


Table 2. Predicted Probabilities of House and Senate Electoral Success, 2007 (continued)

\begin{tabular}{lcccc}
\hline & $\begin{array}{c}\text { Black } \\
\text { Density } \\
\text { Region }\end{array}$ & $\begin{array}{c}\text { State } \\
\text { Ideology }\end{array}$ & $\begin{array}{c}\text { House } \\
\text { Predicted } \\
\text { Probability }\end{array}$ & $\begin{array}{c}\text { Senate } \\
\text { Predicted } \\
\text { Probability }\end{array}$ \\
\hline New York & 0.25 & -3.10 & 0.72 & 0.72 \\
North Dakota & 0.00 & -26.6 & 0.34 & 0.13 \\
Ohio & 0.14 & -10.1 & 0.64 & 0.54 \\
Oklahoma & 0.11 & -27.3 & 0.25 & 0.10 \\
Oregon & 0.02 & -7.90 & 0.77 & 0.67 \\
Pennsylvania & 0.00 & -10.6 & 0.73 & 0.59 \\
Rhode Island & 0.07 & -2.10 & 0.83 & 0.80 \\
South Dakota & 0.01 & -24.1 & 0.40 & 0.17 \\
Utah & 0.01 & -28.0 & 0.31 & 0.10 \\
Vermont & 0.01 & -11.4 & 0.71 & 0.56 \\
Washington & 0.09 & -5.90 & 0.76 & 0.70 \\
West Virginia & 0.03 & -9.20 & 0.74 & 0.62 \\
Wisconsin & 0.01 & -10.5 & 0.72 & 0.59 \\
Wyoming & 0.01 & -17.8 & 0.56 & 0.34 \\
\hline
\end{tabular}

\section{Dependent Variable}

Legislative Electoral Success. For our analysis, the dependent variable is the probability of African Americans reaching population and legislative proportionality. Therefore, states and congressional districts that are within three percentage points of population proportionality receive a value of one. All states that do not attain legislative and population proportionality receive a value of zero.

\section{Independent Variables}

Black Density Factor. Measures the potential influence of black Americans at the state level. Addressing each state individually, we use the number of blacks as the numerator, and the total state population as the divisor, to find the proportion of the state population that is African American.

State Ideology. Measures a state's conservatism: the scale ranges from -.02 for the least conservative states to a high of -28 for the most conservative states.

Region. A dummy variable. Southern states are scored 1. Other states are scored 0 , using the traditional 11 southern states. ${ }^{3}$ 
The following is the full equation used to estimate the predicted probabilities in the analysis as defined with our previous discussion of the variables:

loge (Odds House Legislative Electoral Success) $=a+b 1$ Black

DensityFactor $_{i}-$ b2 South $_{i}-$ b3 State Ideology $y_{i}+\lambda_{i}$.

loge (Odds Senate Legislative Electoral Success) $=a+b 1$ Black DensityFactor $_{i}-b 2$ South $_{i}-b 3$ State Ideology $y_{i}+\lambda_{i}$.

The dependent variable describing House and Senate electoral success takes into account the black population and the percentage of African Americans from both houses, except in the case of Nebraska where there is only one house. We define legislative electoral success to be when the racial proportion of a state's House and Senate representatives percentage is close to the racial proportion of the state's population, demonstrating black electoral parity. In order to derive a cut point for parity, a paired t-test assessed the differences in the population of the African American population and the total number of seats African American state legislators occupy, by state, for the years 1996 and 2007. The paired t-test enables us to reject the null hypothesis that there is no difference between the two populations. We subsequently used the rounded average difference to establish the three percent parameter for legislative electoral success.

If a state's percentage of African Americans in each house is within one to three percentage points of corresponding with the percentage of blacks in the population, then the state is coded an electoral success. For example, in 1996, Alabama's African American population is 25 percent of the total population. The total seats available in the legislative branch is 140 , 35 Senate and 105 House seats. African Americans hold 26 and 23 percent of the House and Senate seats. Since both these chambers are within three percent of the total African American population of 25 percent, both chambers in 1996 achieved legislative electoral success. However, Georgia's African American population is 27 percent. Both chambers' combined legislative seats is 236 and African Americans hold 18 percent in the House and 20 percent in the Senate, clearly reflecting a legislative electoral failure in 1996.

\section{Findings}

We begin our analysis with a descriptive exploration of black over and underrepresentation in state legislatures. We derived our difference measure by calculating the percentage of African Americans in the state legislatures from the total seats available in both houses. For example, the state of 
Alabama has 140 total legislative seats, and in 1996 there were 140 black representatives, yielding in the House 26 percent and Senate 23 percent. We calculate the percent black population of the state, and subtract the total black population as a percentage of the state's total population and derive the Difference in Black Population, and State Legislative Seats Held by Blacks for seven non-consecutive years. ${ }^{4}$ If blacks are underrepresented then the number is negative and if overrepresented a positive number. Because of the differences were small, we coded the data to reflect degree in over- and underrepresentation. ${ }^{5}$

Table 3 presents a frequency of the categorical data. The data show that 79.7 percent of the aggregate state observation points where African Americans' political influence is underrepresented. In other words, over seven non-consecutive years, African Americans are disproportionately less powerful in electoral representation than their state population suggests in most states, in most years. However, we note that 63 percent of these cases of underrepresentation are marginal, with less than 5 percent difference between ratios of population and state legislative representation. Our observations of severe underrepresentation indicate that 6 percent of the cases reflect substantive differences. Moreover, all the severe deviations are cases of underrepresentation. Clearly, blacks' chances for electoral success are inappropriately limited. The aggregate data for seven years is compelling, and calls for further examination.

We now turn to the disaggregated data for the House and Senate for our two cross-section years of 1996 and 2007. Tables 4 and 5 display under- and overrepresentation using the Region variable, separating Southern states from other states. We find that no Southern legislative House chamber displays evidence of legislative-population parity, meaning there are no cases

\section{Table 3. Difference in State Black Population and Legislative Representation}

\begin{tabular}{lccc}
\hline $\begin{array}{l}\text { Underrepresentative/ } \\
\text { Overrepresentative }\end{array}$ & Frequency & Percentage & $\begin{array}{l}\text { Cumulative } \\
\text { Percentage }\end{array}$ \\
\hline-3 (Severe underrepresentation) & 22 & 6.3 & 6.3 \\
-2 (Moderate underrepresentation) & 36 & 10.3 & 16.3 \\
-1 (Marginal underrepresentation) & 221 & 63.1 & 79.7 \\
1 (Marginal overrepresentation) & 70 & 20 & 99.7 \\
2 (Moderate overrepresentation) & 1 & .3 & 100 \\
Total & 350 & 100 & 90 \\
Source: National Council of State Legislatures, Years: 1992, 1994, 1996, 2001, 2003, 2007, and \\
2009.
\end{tabular}




\section{Table 4. Difference in State Black Population and Legislative Representation by Region, 1996}

\begin{tabular}{lcrrr}
\hline \multirow{2}{*}{$\begin{array}{l}\text { Underrepresentation/ } \\
\text { Overrepresentation }\end{array}$} & \multicolumn{2}{c}{ House* } & \multicolumn{2}{c}{ Senate } \\
& South & Non-South & South & Non-South** \\
\hline -3 (Severe underrepresentation) & $25 \%$ & $2 \%$ & $17 \%$ & $3 \%$ \\
-2 (Moderate underrepresentation) & $33 \%$ & $2 \%$ & $58 \%$ & $8 \%$ \\
-1 (Marginal underrepresentation) & $33 \%$ & $61 \%$ & $25 \%$ & $57 \%$ \\
1 (Marginal overrepresentation) & $8 \%$ & $16 \%$ & $0 \%$ & $11 \%$ \\
2 (Moderate overrepresentation) & $0 \%$ & $0 \%$ & $0 \%$ & $5 \%$ \\
0 (Legislative/Population Parity) & $0 \%$ & $18 \%$ & $0 \%$ & $16 \%$ \\
*The total values for the House and Senate do not add up to 100\% because of rounding. \\
**The state of Nebraska is excluded because it has one chamber. \\
Source: National Council of State Legislatures, 1996. \\
\hline
\end{tabular}

\section{Table 5. Difference in State Black Population and Legislative Representation by Region, 2007}

\begin{tabular}{lcrrr}
\hline \multirow{2}{*}{$\begin{array}{l}\text { Underrepresentation/ } \\
\text { Overrepresentation }\end{array}$} & \multicolumn{2}{c}{ House* } & \multicolumn{2}{c}{ Senate } \\
& South & Non-South & South & Non-South** \\
\hline -3 (Severe underrepresentation) & $25 \%$ & $0 \%$ & $25 \%$ & $5 \%$ \\
-2 (Moderate underrepresentation) & $33 \%$ & $5 \%$ & $50 \%$ & $5 \%$ \\
-1 (Marginal underrepresentation) & $33 \%$ & $53 \%$ & $17 \%$ & $54 \%$ \\
1 (Marginal overrepresentation) & $0 \%$ & $21 \%$ & $8 \%$ & $11 \%$ \\
2 (Moderate overrepresentation) & $0 \%$ & $3 \%$ & $0 \%$ & $5 \%$ \\
0 (Legislative/Population Parity) & $8 \%$ & $18 \%$ & $0 \%$ & $19 \%$ \\
*The total values for the House and Senate do not add up to 100\% because of rounding. \\
**The state of Nebraska is excluded because it has one chamber. \\
Source: National Council of State Legislatures, 2007. \\
\hline
\end{tabular}

where the legislative chambers reflect the states' black population proportionately: 91 percent of the Southern House chambers are marginal to severely underrepresented. Eight percent show marginal overrepresentation. Further disaggregation shows that in 1996, 25 and 33 percent of these Southern chambers were severe to moderately underrepresented, effectively reflecting less power in relation to their population.

If we look at non-Southern states, we find a very different story. In this case, 65 percent of these chambers were marginally to severely underrepresented, with 61 percent of the cases falling into the marginal category. We find moderate to severe underrepresentation in 4 percent of 
non-Southern states, compared to 58 percent in Southern states. Also in the non-South we find a felicitous 34 percent of observations where there is legislative-population parity or marginal overrepresentation.

A look at the Senate chambers in Southern legislatures show that 100 percent of the chambers marginally to severely underrepresent African Americans, even less parity than in the House. A full 75 percent of Senate chambers in the South moderately to severely underrepresent African American voters. However, only 11 percent of the non-Southern Senate chambers moderately or severely underrepresent African American voters. Moreover, in 16 percent of the non-Southern Senate chambers, African Americans were marginal to moderately overrepresented. This provides evidence there were opportunities for political success for African Americans in 1996. Next we describe differences between 1996 and 2007.

In Table 5, we find a similar scenario in the Southern House chambers: again 58 percent moderately to severely underrepresented black voters, and 41 percent demonstrated parity or marginal imbalance. There was significant improvement in the non-South, reflecting important strides toward legislative success. In 2007, a full 95 percent of the House chambers show electoral success (defined as marginal underrepresentation or better.) We find no chambers where there is severe underrepresentation in the House.

However, the case for the Senate Southern chambers is mixed. Again we find 75 percent of states having moderate to severe underrepresentation of blacks in Southern Senates. However, 8 percent of the states moved from marginal underrepresentation to marginal overrepresentation. In nonSouthern states' Senates, there were only slight changes between 1996 and 2007. These are compelling and interesting observations, but we need to further assess these compilations and the associational relationships before moving to our probability profile to examine legislative electoral success.

\section{Associational Relationship of Key Variables}

Table 6, Correlates of House and Senate Electoral Success, 1995-1996, displays the inter-correlation of geographic and ideological variables with five significant correlations with region and state ideology representing four of the five significant pairings. A positive relationship exists between region and black density factor with a value of .729. While not as strong, there is a statistically significant and positive relationship between region and state ideology, with a coefficient of .477. Our independent variables of interest are region, state ideology and black density factor. No statistically significant correlation exists between region, black density and African Americans' electoral success. However, there is a statistically significant relationship between state ideology and electoral success, with a coefficient at .436 in the House and .330 in the Senate. 


\section{Table 6. Matrix of Correlates of Legislative Electoral Success, 1995-1996}

\begin{tabular}{|c|c|c|c|c|c|}
\hline & Region & $\begin{array}{c}\text { State } \\
\text { Ideology }\end{array}$ & $\begin{array}{c}\text { Black } \\
\text { Density } \\
\text { Factor }\end{array}$ & $\begin{array}{l}\text { House } \\
\text { Electoral } \\
\text { Success }\end{array}$ & $\begin{array}{c}\text { Senate } \\
\text { Electoral } \\
\text { Success }\end{array}$ \\
\hline Region & 1.00 & & & & \\
\hline State Ideology & $-.447 * *$ & 1.00 & & & \\
\hline Black Density Factor & $.729 * *$ & -.197 & 1.00 & & \\
\hline House Electoral Success & -.210 & $.436 * *$ & -.237 & 1.00 & \\
\hline Senate Electoral Success & -.237 & $.330 *$ & -.193 & $.477 * *$ & 1.00 \\
\hline \multicolumn{6}{|c|}{$\begin{array}{l}\text { Note: Black density is derived from the U.S. Census estimated population data for } 1995 \text { using the } \\
\text { square miles of each state. However, the electoral success and state ideology use the available legis- } \\
\text { lative data for } 1996 \text {. Population increases are more gradual from year to year, than decades; thus, we } \\
\text { are comfortable with the two-year difference and its reliability. } \\
\text { *Correlation is significant at the } 0.05 \text { level ( } 2 \text {-tailed). }{ }^{* *} \text { Correlation is significant at the } 0.01 \text { level } \\
\text { (2-tailed). }\end{array}$} \\
\hline
\end{tabular}

While we see the same five significant pairings, there is one notable difference. The significant levels for state ideology and electoral success in the House and Senate have switched. It is clear the difference in relationship between 1996 and 2007 (Table 7) is consistent with the observations in Tables 4 and 5 where there are significant differences in the Senate and less positive movement in the House. Overall, we have witnessed a small

\section{Table 7. Matrix of Correlates of Legislative Electoral Success, 2005-2007}

\begin{tabular}{|c|c|c|c|c|c|}
\hline & Region & $\begin{array}{c}\text { State } \\
\text { Ideology }\end{array}$ & $\begin{array}{c}\text { Black } \\
\text { Density } \\
\text { Factor }\end{array}$ & $\begin{array}{c}\text { House } \\
\text { Electoral } \\
\text { Success }\end{array}$ & $\begin{array}{c}\text { Senate } \\
\text { Electoral } \\
\text { Success }\end{array}$ \\
\hline Region & 1.00 & & & & \\
\hline State Ideology & $-.447 * *$ & 1.00 & & & \\
\hline Black Density Factor & $.705 * *$ & -.165 & 1.00 & & \\
\hline House Electoral Success & -.220 & $.349^{*}$ & -.194 & 1.00 & \\
\hline Senate Electoral Success & -.227 & $.422 * *$ & -.144 & $.561^{*}$ & 1.00 \\
\hline \multicolumn{6}{|c|}{$\begin{array}{l}\text { Note: Black density is derived from the U.S. Census estimated population data for } 2005 \text { using the } \\
\text { square miles of each state. However, the electoral success and state ideology use the available legis- } \\
\text { lative data for } 2007 \text {. Population increases are more gradual from year to year, than decades; thus, we } \\
\text { are comfortable with the two-year difference and its reliability. } \\
\text { *Correlation is significant at the } 0.05 \text { level (2-tailed). }{ }^{* *} \text { Correlation is significant at the } 0.01 \text { level } \\
\text { (2-tailed). }\end{array}$} \\
\hline
\end{tabular}


increase in African Americans' electoral success in the Senate and no real changes in the House.

\section{Logistic Regression and Probability Profiles}

Since we are interested in the factors influencing electoral success, it is important to examine these relationships in the context of probabilities to enhance our understanding. To that end, we utilize the probability profile method. Pollock $(2005,197)$ demonstrates the utility and application of the method using the probability of voting as an example. The utility of logistic regression and its ability to construct probability profiles actually provides significant clarity in understanding the underlying relationships of interest and we use that application to assess the probability of legislative success or failure for African Americans at the state level. For example, if we wanted to know the probability of legislative success using any or all of the variables in our model we would be able to note the difference between states located in the South and account for the varying levels of black density and state ideology.

Although not all of our key variables are significant from 1996 and 2007 we can still advance an analysis using a probability profile for both years in question. The probability profile uses the available information and estimates the probability of the dependent variable, in this case successfully achieving legislative population. The data contained in Tables 8 and 9 displays the probability profile for 1996 and 2007 demarcated by region and displaying the black density factor. ${ }^{6}$

As mentioned earlier, several states have high-density African American populations. New York, for instance, has a high concentration of blacks and the probability of legislative electoral success for the House in 1996 is high, while their chance in the Senate is lower. However, in 2007 we note that African Americans were able to achieve legislative success in New York for both chambers with a probability of .72, respectively. However, we note a 20 percent decline in the House probability from 1996 to 2007. The small change in black density factor may be a factor here. We see that in 1996 the New York State Assembly and Senate African American seat proportions are 16 and 10 percent respectively. In the case of the Senate in 1996, it would receive a value of 0 because it failed to reach populationlegislative parity. However, the Assembly received a value of 1 because it was within range of population-legislative parity by reaching 16 percent of the seats which reflects the African American state population. Therefore, in the Assembly in 1996, African Americans achieved more electoral success than in the Senate. However, in 2007 there was a dramatic shift in the representation of African Americans in the New York State legislature. While the 


\section{Table 8. Logit Prediction of Electoral Success for House and Senate, 1996}

\begin{tabular}{lcccc}
\hline & \multicolumn{2}{c}{ House Model } & \multicolumn{2}{c}{ Senate Model } \\
Independent Variable & Coefficient & $\begin{array}{c}\text { Standard } \\
\text { Errors }\end{array}$ & Coefficient & $\begin{array}{c}\text { Standard } \\
\text { Errors }\end{array}$ \\
\hline Black Density Factor & -6.005 & 3.784 & -2.748 & .3685 \\
Region & -1.210 & 1.217 & -.167 & 1.269 \\
State Ideology & $.158^{*}$ & .060 & $.088^{* *}$ & .051 \\
Constant & 4.357 & & 1.074 & \\
Chi Square & 5.477 & & 5.54 & \\
Log Likelihood & 52.52 & & 58.29 & \\
$\mathrm{p}<.05^{*} ; \mathrm{p}<.10^{* *}$ & & & & \\
\hline
\end{tabular}

African American state population remained at 16 percent, the Assembly and Senate representation were 18 and 22 percent respectively. One could glean from this data that while there has not be a significant increase in the overall population, the change in black density from .21 to .25 is likely to have influenced the change.

Georgia is a southern state where despite a high African American population, they have not been able to achieve legislative electoral parity. There is some difference in Georgia's probability profile for both the House and Senate in 1996 and 2007. We see that Georgia's African American state population was 27 percent in 1996, and 29 percent in 2007 . While these are

Table 9. Logit Prediction of Electoral Success for House and Senate, 2007

\begin{tabular}{lcccc}
\hline & \multicolumn{2}{c}{ House Model } & \multicolumn{2}{c}{ Senate Model } \\
Independent Variable & Coefficient & $\begin{array}{c}\text { Standard } \\
\text { Errors }\end{array}$ & Coefficient & $\begin{array}{c}\text { Standard } \\
\text { Errors }\end{array}$ \\
\hline Black Density & -3.289 & 3.230 & -1.830 & 3.366 \\
Region & -.247 & 1.158 & -.283 & 1.309 \\
State Ideology & $.102^{*}$ & .052 & $.141^{*}$ & .063 \\
Constant & 2.092 & & 1.868 & \\
Chi Square & 10.934 & & 5.920 & \\
Log likelihood & 59.23 & & 53.14 & \\
$\mathrm{p}<.05$ & & & & \\
\hline
\end{tabular}


high percentages, the state ideology ranking of -17.7 reflects a conservative population. African Americans' seat total in the House increased by 6 percent yielding an 8-point increase in probability that African Americans will attain electoral success. The overall, smaller nature of the House districts may influence this change. While in the Senate we see a decrease in failure, with a probability of .15 , we note no substantive difference in decreasing failure. This is not too surprising considering there was virtually no change in the percentage of African Americans serving in the Senate. The historic nature of race relations and Georgia's moderate to extreme conservatism may largely explain the low overall predicted probability of electoral success; at the same time, chances are better today than earlier.

Evidence presented in this manuscript clearly shows support for the first hypothesis, that African American candidate electoral success for state legislative elections is not dependent on black density. At the state level, black density does not have a significant relationship to the electoral success of black candidates in state legislative elections. This finding is contrary to the expectations of the previous literature.

We have only scant evidence to support of the second hypothesis, that African American candidates are less likely to win in conservative states. In 1996, conservative states did affect the electoral success of African American candidates in state legislative elections. By 2007, this effect dissipated. Exactly why this is the case is still a mystery. Most likely, it is some combination of increased acceptance of African American candidates in conservative states and settled gerrymandered districts that are consistently conducive to electing African American candidates.

Finally, the evidence in this manuscript supports the third hypothesis, that there is no significant difference between the South and non-South in the likelihood of African American candidates' electoral success in state legislative elections. This is important because, unlike previous literature, our findings are not overly deterministic: black candidates can win anywhere.

\section{Discussion}

In many state legislatures, African Americans remain underrepresented when comparing the proportion of black representatives to the proportion of the black population. However, there is no easy answer as to why that is the case. The density of the African American population or the absolute size of the black population is no guarantee that African American candidates will do better or worse. As Tables 6 and 7 demonstrate, the statistical significance of region is losing its grip, although there are still challenges in the South. This makes intuitive sense; we would expect one of the long-term 
effects of the Voting Rights Act to permanently improve the odds of African American candidates in the South (Bullock and Gaddie 2010).

However, a potential roadblock in black electoral success is state ideology, which is more significant than merely being in the South. This probably means that black electoral failures in conservative states are just as likely to be a function of black candidates' Democratic identity as they are a function of their race. However, Mississippi leads the nation in the number of elected African American officeholders, with more than 900 elected black officials (Bositis 2002). Few would deny the conservative quality of Mississippi politics, but this example shows that black candidates can succeed in conservative states. This development was unthinkable thirty years ago.

The results in this manuscript indicate that researchers must update their prior understanding of the limitations of African American electoral success. In 2008, Barack Obama proved, anecdotally, that African American candidates can have broad appeal in areas of the country that political science once thought off-limits to black electoral success. Our understanding of racially motivated voters and electoral geography must keep pace with real world changes in America's political and racial landscape. In 2006 and 2008 the Democratic Party fielded successful candidates in areas where the Party had long been dormant. This renaissance indicates it is possible for Democratic standard-bearers, black or white, to compete successfully in areas where pundits thought it impossible.

Just as important, the ability of African Americans to achieve electoral success improved considerably from 1996 to 2007. These results were not isolated in the non-South: Alabama, Florida and Texas each elected more African Americans than their population would suggest. This could be the result of an increase in the absolute number of elected black officials in the South, and concomitant acceptance of black office holders. Because more than half of all African Americans live in the South it makes sense that Black candidates would eventually succeed there. A second shift from 1996 to 2007 is the evolution of political coalitions. Hispanic voters often lean toward Democratic ideology and they can support blacks' electoral success. In hindsight, perhaps we should not have been so surprised at Obama's 2008 electoral victory in Florida, North Carolina or Indiana or his primary win in Iowa.

\section{NOTES}

${ }^{1}$ Their research focused on the time frame 1970-1985. At that time, a greater portion of African American elected officials served in local office. For instance, only 20 African Americans served in the 99th Congress (1985-1987) compared to 39 serving in the 111th Congress (2009-2011). 
${ }^{2}$ In particular, see Shaw v. Reno (1994).

${ }^{3}$ See Table 1 for the list of southern states.

${ }^{4}$ The National Council of State Legislatures data from 1992, 1994, 1996, 2001, 2003, 2007, and 2009 are the years in the analysis for under- and overrepresentation for Table 3.

${ }^{5}$ To capture the difference in representation, we place these differences on an ordinal scale. We then assess each over- and underrepresentation. We begin with underrepresented states where the values between 0 and $.049(-/+)$ percent is scored -1 for underrepresented and 1 for overrepresented. Moderately over- and underrepresented are differences between 0.05-0.99 percent. All negative values in this range are coded -2 and all positive values we code 2 . The final category is severe over- and underrepresentation; all differences of 0.10 percent and above where all negative values are coded -3 .

${ }^{6}$ The predicted probabilities in italics in the House/Senate columns were coded a value of one for electoral success.

\section{REFERENCES}

Barrett, Edith J. The Policy Priorities of African American Women in State Legislatures. Legislative Studies Quarterly 20:223-247.

Bobo, Lawrence, and Franklin Gilliam, Jr. 1990. Race, Sociopolitical Participation, and Black Empowerment. American Political Science Review 84:377-393.

Bositis, David A. 1998. The Future of Majority-Minority Districts and Black and Hispanic Legislative Representation. Pp. 9-42 in Redistricting and Minority Representation: Learning from the Past, Preparing for the Future. Washington, DC: Joint Center for Political and Economic Studies.

Bositis, David A. 2002. Black Elected Officials: A Statistical Summary, 2000. Washington, DC: Joint Center for Political and Economic Studies.

Brace, Kimball, Bernard Grofman, and Lisa Handley. 1987. Does Redistricting Aimed to Help Blacks Necessarily Help Republicans? Journal of Politics 49:169-185.

Bullock III, Charles S. 1975. The Election of Blacks in the South: Preconditions and Consequences. American Journal of Political Science 19:727-739.

Bullock III, Charles S., and Richard Dunn. 1999. The Demise of Racial Districting and the Future of Black Representation. Emory Law Journal 48:1209-1253.

Bullock III, Charles S., and R. Keith Gaddie. 2010. The Triumph of the Voting Rights Act in the South. Norman: University of Oklahoma Press.

Burns, Nancy, Kay Schlozman, and Sidney Verba. 2001. The Private Roots of Public Action: Gender, Equity, and Political Participation. Cambridge, MA: Harvard University Press.

Canon, David. 1999. Race, Redistricting, and Representation: The Unintended Consequences of Black Majority Districts. Chicago: University of Chicago Press.

Citrin, Jack, Donald Philip Green, and David Sears. 1990. White Reactions to Black Candidates: When Does Race Matter? Public Opinion Quarterly 54:74-96.

Conover, Pamela. 1984. The Influence of Group Identifications on Political Perception and Evaluation. Journal of Politics 50:985-1010.

Davis, Darren, and Ronald E. Brown. 2002. The Antipathy of Black Nationalism: Behavioral and Attitudinal Implications of an African American Ideology. American Journal of Political Science 46:239-252. 
Dawson, Michael C. 1994. Behind the Mule: Race and Class in African American Politics. Princeton, NJ: Princeton University Press.

Engstrom, Richard, and Michael McDonald. 1981. The Underrepresentation of Black on City Councils: Comparing the Structural and Socioeconomic Explanations for South/Non-South Differences. Journal of Politics 44:1088-1199.

Fenno, Richard. 2003. Going Home: Black Representatives and Their Constituents. Chicago: University of Chicago Press.

Feree, Myra. 1974. A Woman for President? Changing Responses: 1958-1972. Public Opinion Quarterly 38: 390-399.

Gay, Claudine. 1999. Choosing Sides: Black Electoral Success and Racially Polarized Voting. Paper presented at the Annual Meeting of the American Political Science Association. Atlanta.

Gay, Claudine. 2001. The Effect of Black Congressional Representation on Political Participation. American Political Science Review 95:589-602.

Grofman, Bernard, and Lisa Handley. 1989a. Black Representation: Making Sense of Electoral Geography at Different Levels of Government. Legislative Studies Quarterly 14:265-279.

Guinier, Lani. 1994. The Tyranny of the Majority: Fundamental Fairness in Representative Democracy. New York: Free Press.

Hajnal, Zoltan. 2001. White Residents, Black Incumbents, and a Declining Racial Divide. American Political Science Review 95:603-617.

Henry, Charles. 1982. Racial Factors in the 1982 California Gubernatorial Campaign: Why Bradley Lost. Pp. 76-94 in The New Black Politics, 2nd ed., eds. Michael B. Preston, Lenneal J. Henderson, Jr., and Paul L. Puryear. New York: Longman.

Hero, Rodney and Caroline Tolbert. 1995. Latinos and Substantive Representation in the U.S. House of Representatives: Direct, Indirect, or Nonexistent? American Journal of Political Science 39:640-652.

Highton, Benjamin. 2004. White Voters and African American Candidates for Congress. Political Behavior 26:1-25.

Jones, Charles, and Michael Clemons. 1993. A Model of Racial Crossover Voting: An Assessment of the Wilder Victory. Pp. 1128-1146 in Dilemmas of Black Politics: Issues of Leadership and Strategy, ed. Georgia Persons. New York: HarperCollins.

Lublin, David. 1997. The Paradox of Representation: Racial Gerrymandering and Minority Interests in Congress. Princeton, NJ: Princeton University Press.

McDermott, Monika L. 1998. Race and Gender Cues in Low-Information Elections. Political Research Quarterly 51:895-918.

Moskowitz, David and Patrick Stroh. 1994. Psychological Sources of Electoral Racism. Political Psychology 15: 307-329.

Newman, Brian and John Griffin. 2005. Does Descriptive Representation Produce Political Equality? Paper presented at the Annual Meeting of the Midwest Political Science Association, Chicago.

Philpot, Tasha, and Hanes Walton. 2007. One of Our Own: Black Female Candidates and the Voters Who Support Them. American Journal of Political Science 51:49-62.

Pollock, Philip H. 2005. The Essential of Political Analysis. Washington, DC: CQ Press.

Preuhs, Robert R. 2006. The Conditional Effects of Minority Descriptive Representation: Black Legislators and Policy Influence in the American States. Journal of Politics 68:585-599.

Reeves, Keith. 1997. Voting Hopes or Fears? White Voters, Black Candidates and Racial Politics in America. New York: Oxford University Press. 
Schreiber, E.M. 1978. Education and Change in American Political Opinions on a Woman for President. Public Opinion Quarterly 42:171-182.

Shingles, Richard. 1981. Black Consciousness and Political Participation: The Missing Link. American Political Science Review 75:76-91.

Sigelman, Carol, Lee Sigelman, Barbara Walkosz, and Michael Nizt. 1995. Black Candidates, White Voters: Understanding Racial Bias in Political Perceptions. American Journal of Political Science 39:243-265.

Sigelman, Lee and Susan Welch. 1984. Race, Gender, and Opinion toward Black and Female Presidential Candidates. Public Opinion Quarterly 48:467-475.

Sonenshein, Raphael J. 1990. Can Black Candidates Win Statewide Elections? Political Science Quarterly 105:219-241.

Squire, Peverill. 1992. Challenger Quality and Voting Behavior in U.S. Senate Elections. Legislative Studies Quarterly 17:247-263.

Tajifel, Henri. 1978. Differentiation Between Social Groups: Studies in the Social Psychology of Intergroup Relations. London: Academic Press.

Tate, Katherine. 2003. Black Faces in the Mirror: African Americans and Their Representatives in the U.S. Congress. Princeton, NJ: Princeton University Press.

Terkildsen, Nayda. 1993. When White Voters Evaluate Black Candidates: The processing Implications of Candidate Skin Color, Prejudice, and Self-monitoring. American Journal of Political Science 37:1032-1053.

Voss, D. Stephen, and David Lublin. Black Incumbents, White Districts: An Appraisal of the 1996 Congressional Elections. American Politics Research 29:141-182.

Williams, Linda F. 1990. White/Black Perceptions of the Electability of Black Political Candidates. National Political Science Review 2:45-64.

Yates, Jeff, and Richard Fording. 2005. Politics and State Punitiveness in Black and White. Journal of Politics 67:1099-1121.

Murray, Richard, and Arnold Vedlitz. 1977. Race, Socioeconomic Status, and Voting Participation in Large Southern Cities. Journal of Politics 39:1064-1072.

Piliawsky, Monte. 1989. Racial Politics in the 1988 Presidential Election. The Black Scholar 20:1-11. 